\title{
Efficacy of Written Corrective Feedback as a Tool to Reduce Learners' Errors on L2 Writing
}

\author{
Aisha Tanveer ${ }^{1}$, Mehwish Malghani ${ }^{1}$, Durdana $\mathrm{Khosa}^{1} \&$ Maria Khosa ${ }^{2}$ \\ ${ }^{1}$ Department of English, SBK Women's University, Quetta, Pakistan \\ ${ }^{2}$ Department of English, BUITEMS, Quetta, Pakistan \\ Correspondence: Maria Khosa, Department of English, Balochistan University of Information Technology, \\ Engineering \& Management Sciences, Baleli Quetta, Balochistan, Pakistan. E-mail: khosa.maria@yahoo.com
}

Received: April 6, 2018 Accepted: May 3, 2018 Online Published: June 9, 2018

doi:10.5539/ijel.v8n5p166 URL: https://doi.org/10.5539/ijel.v8n5p166

\begin{abstract}
Over the last few decades, considerable research has been done to investigate the role of written corrective feedback in SLA classrooms. However, early researches suffered from major design flaws and consequently failed to draw any definite conclusions. In order to move this line of research it is important to analyze the issue in EFL/ESL settings. This research study, by applying quantitative research design, seeks to investigate the effectiveness of WCF on 30 low-intermediate EFL learners and their error reduction rate on pre, post and delayed posttest. Two different types of WCF (direct and indirect metalinguistic) were provided on two error categories, i.e. articles and past tense. Statistical analysis indicated that both treatment groups performed significantly better than control group on subsequent drafts. Thus, the present study by proving the efficacy of WCF at least on above mentioned error categories strengthens the case in favor of WCF in L2 classrooms.
\end{abstract}

Keywords: written corrective feedback, second language writing, direct metalinguistic feedback, indirect metalinguistic feedback

\section{Introduction}

\subsection{Introduce the Problem}

Writing is an important skill that requires conscious effort, continuous practice and a certain level of proficiency in targeted language forms and structures. Teachers in both ESL and EFL contexts are concerned with the writing proficiency of their learners and opt for different strategies to ensure the effectiveness and clarity of learners' ideas on L2 composition.

In 1990s researchers and teachers of second language acquisition (SLA) discovered that students in second language classrooms were able to excel in their speaking and reading skills but performed poorly on their writing tasks. Hence they concluded that mere exposure to language is not sufficient for learners, they need to be informed about their interlanguage errors (Lightbown \& Spada, 2013). Furthermore, as Myles (2002) puts it, academic writing for L2 learners is a complex task as compared to the students writing in their native language because for L2 writers it's a "two way process" in which they continuously develop, compose, edit and reformulate texts and ideas side by side (Scardamalia \& Bereiter, 1987). Therefore, a great number of learners around the world are enrolled in SLA writing classes with the purpose of improving their proficiency in L2 writing. These writing programs incorporate several grammar and vocabulary activities to enhance learners' linguistic and grammatical accuracy, which is considered an essential component for good writing skills. Learners are encouraged to produce error free assignments (Myles, 2002) and when the said assignments are handed back to the learners, they take them back with an expectation that their teachers must have corrected them. Few studies, that investigated the perception of both learners and teachers regarding the use of error correction, indicate learners' approval as well as of teachers, who consider it their professional responsibility to provide students with correction (Chunhong \& Griffiths, 2012).

Despite the agreement of teachers and students regarding the use of corrective feedback, it has still been subjected to fierce controversy. Theorists, researchers and pedagogists from SLA and from the field of education were busy in examining effectiveness of corrective feedback since the publication of Truscott's (1996) study in which he regarded corrective feedback as ineffective and harmful for learners who wished to develop their L2. 
He suggested that by correcting errors the teachers may ignore other complex processes that are essential for language learning, therefore, both teachers and students should focus more on writing practice alone.

Since then there has been continuous debate between the supporters and opponents of the notion on whether written corrective feedback is an effective learning tool that helps learners to improve their writing accuracy or otherwise. Major opponent in this regard is Ferris $(1999,2004)$, who through her detailed analysis of Truscott's claims, reported that the conclusions drawn by the said author are against grammar correction and are "premature and overly strong" (Ferris, 1999, p.2). Furthermore, early studies were inconsistent and produced dubious findings because of their flawed design. These studies ignored the factors associated with the learners', i.e. language learning context, proficiency level, age, and educational / learning context that directly influences learners' ability to receive and process written corrective feedback. Moreover, they didn't incorporate control group and delayed posttest to investigate long-term gains (Bitchener, 2008; Ferris, 2004; Ferris \& Hedgecock, 1998). This leaves an ample room for further research in this domain.

The present study attempts to address these flaws by integrating a control group, in order to check the validity of written corrective feedback only. The study also conducts immediate and delayed posttest to examine the short term and long term gains, along with individual learner's variable i.e. proficiency level. The study is conducted at government secondary school Quetta, as this issue has not been addressed before particularly in this language learning context of EFL learners.

The aim of this research is, firstly to investigate the extent to which focused WCF lead to increase in/ reduction of errors on learners' revised texts. Secondly, to determine the extent to which focused WCF lead to increase in/ reduction of errors on learners' new piece of writing on immediate and delayed posttest. And finally, to find out the effective type (direct/indirect) in addressing low-intermediate learners' errors.

The present study is delimited to small sample size of 30 participants with low- intermediate level of proficiency only. The focus of this research is on two types of written corrective feedback (direct metalinguistic and indirect metalinguistic). These types were used to correct two categories of grammatical errors i.e. articles and past tense which were further delimited to only two uses of English Article system (A and THE for first and second mention). The focused approach to errors and two types of feedback allowed researcher to contribute further in this domain. In addition, this study did not include other variables such as aptitude, motivation; contextual settings of learner that could influence the effectiveness of CF, rather it only analyzed the effectiveness of CF with regards to the proficiency level of learners. This study was also limited to EFL (English as foreign language) context where the participants learnt their L2 as a single subject; therefore the results can't be generalized to ESL (English as a second language) context.

\subsection{Operational Definitions}

In this study L2 is taken as second language of learners i.e. English.

\subsection{Literature Review}

Corrective feedback has been a topic of considerable debate in numerous fields of research. The phenomenon has been referred to as negative evidence in second language acquisition, corrective feedback in pedagogical context and negative feedback in psychology (Schachter, 1991). Similarly the term has been given multiple names within the single domain of educational L2 research. Some addressed this phenomenon as error feedback (Chandler, 2003) or grammar correction (Hendrickson, 1978; Truscott, 2007), error correction (Bitchener \& Ferris, 2012) written feedback (Cramp, 2011; Elwar \& Crono, 1985; Glover \& Brown, 2006), and teachers' response (Ferris, 1995).

Corrective feedback takes the form of teacher's correction in order to make the learners aware of their mistakes. As advocated by Lightbown and Spada (1999), that "Any indication to the learners' mistakes that their use of the target language is incorrect" is CF (p.172). Similarly Li (2010) regards CF as teachers' response towards those utterances of learners that deviate from universally acknowledged rules of L2. Chaudron (1988) on the other hand, views CF as "any teachers' behavior following an error that minimally attempts to inform the learners of the fact of error, this response of teacher leads learners to modify their interlanguage by eliminating error from further production" (p. 150). Long (1996), Gas and Selinker (2001) further divided feedback into positive and negative evidence. Positive evidence provides learners with the information about their correct use of language while negative evidence deals with correcting learners' erroneous utterances. Hattie, Biggs and Purdie (1996) found CF as an inevitable tool to enhance L2 proficiency; therefore, it should be practiced widely in both EFL and ESL classrooms.

With the rise of theories explaining the ways human being acquire L2, few pedagogical opinions and supposition 
had been investigated in earlier studies. But these studies suffered from design flaws and produced inconclusive results that proved CF as ineffective, and on whose basis Truscott $(1996,1999)$ centered his claims of error correction as harmful. Different research design including highly controlled experimental studies were conducted in laboratories, quasi-experimental studies in schools with controlled and experimental groups and few purely descriptive studies were conducted to examine real life error treatment and teacher pupil interaction. It was after Truscott's (1996) publication that research in WCF began. Few studies regarded feedback as completely redundant (Truscott, 1996, 1999; Truscott \&Hsu, 2008) while some other studies (Fazio, 2001; Polio \& Fleck, 1998; Rob, Ross, \& Shortreed, 1986) found feedback non-beneficial but did not claim the use of WCF as completely redundant. While Hyland and Hyland (2001), Ferris (1999, 2006), Ferris and Robert (2001), Guenette (2007) and Lalande (1982) opined written feedback as a vital instrument. Before Truscott's claims; teacher, pedagogists and researchers were busy in answering the pedagogical issues such as finding different ways of providing feedback on different error categories. Thus the utmost concern of SLA researchers over three decades was to investigate different types (direct/indirect) by giving comprehensive feedback on all of learners' errors. Theories and studies supporting indirect approach argued that it helps learners to activate their cognition and "problem solving skills" (Ferris, 2004, p.60), consequently it enhances partially acquired knowledge of grammar and linguistic rules which ultimately lead to long-term retention of those forms. Semke (1984) in his quasi-experimental study investigated $141 \mathrm{EFL}$ students studying German in America. Three treatment groups received direct WCF, direct plus commentary and indirect (codes) respectively, while control group received comments only. The research found no significant differences among experimental groups on correctness, fluency or overall language proficiency rather adverse effects were analyzed when learners were required to correct themselves through indirect WCF. Fathman and Whalley (1990) in their study provided 4 types of feedback on both grammar and content. The findings suggested that the group who received grammar correction outperformed those receiving content feedbacks. Along with Fathman and Whalley (1990), Ashwell (2000) found improvement in control group's writing over time because continuous writing helps them to improve. On the other hand, the groups who received direct or indirect feedback throughout their written drafts performed slightly better than those who didn't, but the differences were not significant. Lalande (1982) divided his $60 \mathrm{EFL}$ students with an intermediate proficiency, into two control groups who received direct error correction and two treatment groups that received indirect error correction. The findings revealed that treatment group performed better in interpreting codes and correcting themselves as compared to the control group that received explicit correction. Rob et al. (1986) conducted an experimental research on 134 participants to analyze the effects of 4 types of feedback, including direct error correction and three other types of indirect feedback. Study hypothesized the superiority of direct WCF over other forms of feedback. The study investigated the effects on over all coherence and cohesion of learners written texts. Findings reported no significant difference among direct and indirect feedback on learner's revised texts. Range of researches investigating different types of WCF failed to produce conclusive results. Factors pointed out by Russell and Spada (2006) include; different variable, execution design and research methodology hence, making the comparison difficult and consequently these studies failed to declare the superiority of single type of WCF.

The investigation of L2 errors, their possible explanations and solutions had been explored by language theories since 1970. Some of them oppose its position while others argued in favor of CF. The present study endeavors to study the effectiveness of WCF on second language learners performance on past tense and use of articles.

\subsection{Theoretical Foundations}

Questions such as how learners acquire language and whether errors play positive or negative role in the acquisition process of target language are of main interest to SLA scholars and theorists. These concerns gave rise to two major questions: Should errors be viewed negatively and need to be avoided by learners? Or, should errors be viewed positively?, as these inform us about the developmental stage of learners. In order to have an in depth understanding of this issue the researchers delineated some of the theories that are most relevant to error treatment and that either accept $\mathrm{CF}$ as a tool that foster learning or neglect its importance by debunking its practice. Some of these theories are discussed below.

\subsubsection{Behaviorism}

Behaviorists view error as a "sin" and are of the opinion that it should be eliminated from learner's interlanguage (Brooks, 1960). This idea was very influential during 1950 to 1960s. Thus every effort was made to eradicate learners' errors which were thought to interfere inevitably with learners' new habits of L2. The supporters of this theory argued that for effective learning to occur learners must respond to any stimuli correctly and all incorrect responses should be corrected with corrective feedback. The major focus of this approach was on preventing learners from producing errors rather than amending those ill-formed utterances. Consequently, this belief 
resulted in audio-lingual pedagogical method, where students were required to practice correct utterances multiple times and emphasis was on producing error free-utterances. Students spent hours in drilling, memorizing different patterns. Thus Behaviorists view CF as a tool that helps learners develop error free habits.

\subsubsection{Mentalism}

Chomsky (1959) criticized behaviorist's idea by arguing that language learning is an internal process where critical acquisition device helps children to learn languages that exist around them. The acquisition of different language structures depend on different developmental stages of learners; therefore any external feedback or form of instruction shall not help them at all.

According to Bitchener and Ferris (2012), one reason might be the pre-assumed concept that WCF is effective in developing learners' L2, therefore researchers and pedagogist in SLA began to focus their attention on exploring different ways for provision of CF. Meanwhile; Truscott (1996) in his study downplayed the role of WCF, he argued that grammar correction can have negative effects on learners L2 development, as teachers may avoid other complex and important aspect by only focusing on grammatical errors.

Truscott (1996) further questioned teachers' ability to provide effective feedback and learners' ability to comprehend it successfully. He negates the idea of teaching grammar in classrooms, where sudden exposure of targeted forms is not enough for language acquisition, particularly when learners' developmental stages do not correspond with it. The major opponent of Truscott's idea was Ferris $(1999,2004)$. Ferris in her response to Truscott explained that early studies produced deficient results and their findings were inconsistent which leaves room for further research. Some of the contemporary research investigated the theoretical stances as well as the positive or negative claims made by Ferris $(2004,1999)$ and Truscott $(1996)$ respectively and explored the way it leads to attain long or short-term gains.

The earlier studies suffered from major design and implementation flaws, such as there was no execution of real control group, neither any experimental groups were examined to check long term gain on delayed posttest nor they produced new writing tasks. Different writing genres were used in single study. Proficiency level, educational background was not taken into consideration and feedback was provided on all of learners' errors. Few contemporary studies from the domain of SLA and writing composition that attempted to address these flaws are as follows:

Ellis (2009) and Sheen (2011) introduced more refined typology of WCF to analyze the effects more systematically. Focused approach to error correction became the center of attention that supports the theoretical stance of Ellis (2005) and Schmidt (1994) that correction on fewer errors enabled learners to locate their errors, notice the correction and remember it for a longer period of time. Hence, contemporary researches are limited in terms of their focus on English article system, past tense and prepositions only (Bitchener, 2008; Bitchener \& Knoch, 2009a, 2009b; Bitchener, Young, \& Cameron, 2005; Ellis, Sheen, Murakami, \& Takashima, 2008; Sheen, 2007; Sheen, Wright, \& Moldawa, 2009). Bitchener (2008), Bitchener and Knoch (2008) in their studies analyzed three different types of direct feedback i.e. direct WCF, direct oral and written metalinguistic, direct written metalinguistic feedback with different participants in different settings. 75 low-intermediate and 144 international and immigrant learners in respective studies produced pretest, posttest and delayed posttest. The results indicated that experimental groups performed notably better than control group. Sheen, Wright and Moldawa (2009) did a comparative study on focused vs. unfocused feedback by splitting their 80 ESL participants into two experimental (focused, unfocused) and two control (writing practice alone, no feedback) groups. Their study confirmed the findings of Sheen (2007) who found the advantage of focused over unfocused feedback by comparing his treatment groups with control group who received no feedback. Bitchener and Knoch (2009a, 2009b) investigated direct feedback, direct oral and written metalinguistic, direct metalinguistic only. Bitchener and Knoch (2009a) included 39 low-intermediate ESL learners while Bitchener and Knoch (2009b) study dealt with 52 ESL learners. The former study was conducted within the time period of 6 months while latter was a 10 months study. Their findings suggest that learners were able to take benefits from WCF even after the time period of 6 and 10 months. However, their approach to error correction was only confined to two uses of English article system. Bitchener, Young and Cameron (2005) in their experimental study of 53 immigrant learners of intermediate proficiency split them into two direct CF groups, whilst control group received general comment on the overall language accuracy. Results indicated that treatment groups improved significantly but only on articles and past tenses while lacked accuracy on prepositions.

Studies before Truscott found no significant effect of unfocused approach to error correction. Thus few contemporary studies in recent years attempt to address these deficiencies of previous studies by systematically investigating the effects of unfocused feedback. Bitchener (2012) with his non-native learners of Dutch, Ferris 
(2006) with 92 ESL adult learners; Beuningen, De Jong and Kuiken (2008) with 62 German young learners, Beuningen, De Jong and Kuiken ( 2012) with their 268 ESL German Learners and Ellis, Sheen, Murakami and Takashima (2008) with 41 adult ESL learners compared focused and unfocused feedback. The treatment groups in all the above mentioned studies were divided into direct and indirect CF groups. Only few of these studies analyzed the effects on learners' revision (short-term effects) while rest of them examined its effect on post and delayed posttest (long-term effects) on new piece of writing. The results discredited the conclusions drawn by early studies by finding out that both focused and unfocused groups performed extensively better than control groups. However the efficacy focused treatment is proved to be more effective in comparison with unfocused group.

The findings of previous studies described above have claimed the positive effects of WCF but the studies which investigated different types of feedback (direct/indirect) failed to prove the superiority of one type over the other and also failed to determine which type is effective for short or long term gains. Secondly, recent studies gave considerable attention to different direct feedback types and ignored indirect types completely. Furthermore, metalinguistic type of feedback has been investigated by relatively fewer studies which proved the advantage of this type over direct or indirect type but none of the studies used this type in combination with indirect feedback or compared it with direct metalinguistic feedback to analyze which combination is most effective for learners.

Accordingly the present study following Sheen (2011) typology compared direct metalinguistic feedback with indirect metalinguistic feedback to address the deficiencies of previous studies. In addition to this, the present study also considered learners' variable, such as proficiency level and age by picking 30 low-intermediate EFL learners who were relatively young ranging between the ages of 16-18, because the researchers wanted to address the limitation of previous studies where the main focus had been on adult university learners. The research was conducted in an educational setting that had not been examined before, i.e. secondary level EFL learners of Quetta city, in the province of Balochistan.

Focused CF was provided on two error categories i.e. articles and past tense by keeping Bitchener (2012) in mind that correction on range of errors might result in cognitive load and may discourage students when they were unable to correct themselves. Finally following Truscott and Hsu (2008) and Beuningen et al. (2012) suggestion of investigating short and long-term gains, the present study compared learners' pre-test with their revision and I-post-test to analyze short-term gains and D-post-test on new piece of writing to analyze long-term gains. In addition to this, the present study by addressing the limitations of previous studies incorporated control group who produced similar drafts like treatment groups without feedback which was beneficial in investigating Truscott (1996) claims of writing practice alone. Thus the present study by concentrating on the deficiencies of previous studies aimed at contributing to an ongoing debate regarding the positive/negative effects of WCF.

\subsection{Theoretical Framework}

The theoretical framework of this study is drawn from Ferris (2004), who opines that treatment of an error is one of the essentials of L2 writing instruction. She predicted from her conclusion of early researches that learners who received WCF were able to correct themselves on their revision task as compared to those learners who didn't receive feedback. And this indicated that correction on revision might lead learners to improve their linguistic and grammatical accuracy for longer period of time. In addition to this she recommended that in an ideal situation students must be provided with an opportunity to revise their original drafts in a classroom where they would be able to seek advice from their teacher. The provision of grammar instruction that correspond with students' need and integrated with teachers' feedback can enhance learners' writing accuracy.

She further preferred indirect error correction over direct error correction because it led to activate learners "cognitive problem solving skills" (Ferris, 2004, p. 60) and prioritized focused approach to error correction specifically because students can process feedback without any cognitive load and it's not time consuming for teachers as well (Ferris, 1999, 2004). Based on the assumption of Ferris $(1999,2004)$, the present study applied the typology of WCF by Sheen (2011) to investigate the extent with which WCF is effective for learners in an EFL setting.

In order to systematically investigate the effects of written corrective feedback it is important to choose systematically classified types of WCF (Ellis, 2009). Thus a typology of WCF was proposed by Ellis (2009) who called for more carefully designed studies in order to examine the written corrective feedback more effectively and accurately. He categorized his typology on the basis of early published empirical research and common pedagogical practices of feedback in L2 classrooms. Ellis divided WCF types into six different categories.

This typology was later extended and modified by Sheen (2011), though the feedback types were similar across both the original and revised versions, except the slightest alteration and or combination. For example, Ellis 
(2009) characterized direct and indirect types separately from metalinguistic feedback, while Sheen (2011) combined these categories as direct metalinguistic, indirect metalinguistic feedback different from direct and indirect only. Sheen (2011) defined seven types for systematic provision of WCF.

i. Direct non-metalinguistic written correction

It refers to the explicit provision of correct form by replacing the error or by placing the missing word.

ii. Direct metalinguistic error correction

This feedback intends to provide learners with an explanation of their error usually by writing down the explanation of an error at the end of the paper.

iii. Indirect error correction (non-located errors)

Indicating that learner has made an error without underlining or locating the error. The learners are informed about their errors in the margin.

iv. Indirect written correction (located error)

Here the teacher implicitly underlines the error without providing any correction to it.

v. Indirect error correction using error codes

Learners are provided with an implicit feedback through an explicit error code that indicates the type or nature of erroneous utterance e.g. 'SVA' for subject verb agreement, 'WO' for word order and 'PREP' for preposition.

vi. Indirect metalinguistic written correction

Type 2 and 6 are similar in a way that both provide students with an explanation along with example of the rule, but with the distinction of implicit feedback. This feedback provides information of error without providing the correct form. E.g. which helping verb do we use for past continuous tense?

\section{vii. Reformulation}

This type of correction dealt with the overall accuracy of written texts. Reformulation converts erroneous text into error-free writing and learners are left to locate and identify errors by themselves.

Ellis (2009) offered the model which provided a base for Sheen (2011) to develop a more refined typology for better investigation; therefore it is this typology of Sheen (2011) on which this study was formulated. Two out of seven categories i.e. direct metalinguistic feedback and indirect metalinguistic feedback are incorporated as error correction strategies to correct learners errors and to check the efficacy of WCF on their revised and new texts.

\section{Research Methodology}

This study applies the quantitative mode of inquiry to examine the relationship among variables. Experimental research design was adopted by the researchers in which particular treatment was provided to two groups (experimental) and withholding it from the other (control group) to assess the influence of an outcome. The study applied quasi-experimental design to select the sample from the population. During the study, the researchers had access to two of the EFL learners' classrooms who studied English as a single subject. The population for data collection consisted of the female EFL (English as foreign language) learners of Quetta city, at secondary school level.

Through purposive sampling 30 female EFL learners of 10th class were chosen for the study. In the beginning 50 female EFL learners were selected but only 30 learners produced all four drafts consistently during the experiment. Oxford placement test was administered to determine the low-intermediate proficiency learners who were then randomly assigned to two treatmental and one control group with each containing 10 participants. Multiple tools of measurement were used by the researchers for the collection of data. Firstly, Oxford placement test was adopted to measure the proficiency level of selected participants. Secondly, three picture compositions consisting of 6-4 pictures describing a short story were used to make the participants generate writing drafts. Participants were given $30 \mathrm{~min}$ to complete the task. These drafts were then administered to check the error rate of learners in each task. In order to enhance the quality of measurement the written drafts of all four groups were checked by two raters. Thirdly a handout consisting of metalinguistic explanation about the targeted features i.e. articles and past tense was used to provide both the treatment groups with extra information about these forms during the experiment.

\section{Data Analysis}

This section of research paper uses statistical procedures to answer questions concerning the efficacy of written corrective feedback. SPSS was used to run descriptive statistic and one-way ANOVA on all four drafts i.e. 
pre-test, revision and immediate post-test and delayed post-test of learners. Former detailed the means and standard deviations of errors while latter was conducted to see whether the differences were statistically significant between or within groups.

\subsection{Inter-Rater Reliability Check}

Inter-rater reliability was assessed through Pearson Correlation Coefficient to check whether the scores on learners' drafts by two raters were correlated positively or negatively. The results indicated that there is a significant positive correlation between two scores on pre-test, $\mathrm{r}(28)=0.89, \mathrm{P}=.000$, Revision, $\mathrm{r}(28)=0.97, \mathrm{P}$ $=.000$, I-Posttest, $\mathrm{r}(28)=0.97, \mathrm{P}=.000$ and D-posttest, $\mathrm{r}(28)=0.98, \mathrm{P}=.000$. In other words the scores marked by two raters are positively correlated with one another i.e. both the scores increase and decrease at the same level and any disagreement between raters was sorted out through discussion.

\subsection{Analysis of Pre-Test}

Pre-test error scores of three groups were analyzed to probe whether the learners began the experiment with similar error rates or did they differ in terms of their grammatical accuracy. Percentages of errors on per 100 words across three groups are summarized in the Table 1 and descriptive statistics of two experimental and one control group are offered in Table 2.

Table 1. Percentage of errors (sum of errors/sum of words x100)

\begin{tabular}{ll}
\hline Groups & Pre-test \\
& Error Scores \\
\hline Direct metalinguistic & $104.48 \%$ \\
Indirect metalinguistic & $102.59 \%$ \\
Control group & $101.56 \%$ \\
\hline
\end{tabular}

Table 2. Descriptive statistic of error rates across three groups

\begin{tabular}{lll}
\hline Groups & Error Rates in Pre-test & \\
\hline & $\mathrm{M}$ & $\mathrm{SD}$ \\
\hline Direct metalinguistic $(\mathrm{N}=10)$ & 10.4480 & 4.5300 \\
Indirect metalinguistic $(\mathrm{N}=10)$ & 10.2590 & 1.8556 \\
Control group $(\mathrm{N}=10)$ & 10.6830 & 3.8566 \\
Total $(\mathrm{N}=30)$ & 10.1006 & 3.6015 \\
\hline
\end{tabular}

According to the results reported above IMF $(\mathrm{M}=10.25, \mathrm{SD}=1.85)$ and control $(\mathrm{M}=10.10, \mathrm{SD}=3.85)$ groups are similar in terms of their grammatical accuracy. However, a slight difference in the mean score DMF group $(\mathrm{M}=9.35, \mathrm{SD}=4.73)$ can be observed. Therefore, one-way ANOVA was performed to see whether the differences were significant.

Table 3. One-way ANOVA for error score on pre-test

\begin{tabular}{llllll}
\hline & Sum of Squares & Df & Mean Square & F & Sig. \\
\hline Between Groups & 9.129 & 2 & 4.565 & .336 & .718 \\
Within Groups & 367.028 & 27 & 13.594 & & \\
Total & 376.158 & 29 & & & \\
\hline
\end{tabular}

In Table 3 one-way ANOVA between subjects showed that the differences are not significant, $\mathrm{F}(2,27)=.336$, $\mathrm{P}=.718$. Hence, participants were at same level of proficiency in the beginning of the study.

\subsection{Analysis of Revision}

In order to investigate learners' improvement on their revised texts as a result of WCF treatment one-way ANOVA was used to compare the differences between three groups on their written drafts. 
Table 4. Percentage of errors (sum of errors/sum of words x100)

\begin{tabular}{ll}
\hline Groups & $\begin{array}{l}\text { Revision } \\
\text { error scores }\end{array}$ \\
\hline Direct metalinguistic & $40.03 \%$ \\
Indirect metalinguistic & $50.21 \%$ \\
Control group & $98.97 \%$ \\
\hline
\end{tabular}

Table 5. Descriptive statistics of error scores of revision across three groups

\begin{tabular}{lll}
\hline Groups & \multicolumn{2}{l}{ Error rate in Revision } \\
\hline & $\mathrm{M}$ & $\mathrm{SD}$ \\
\hline Direct metalinguistic & 4.0030 & 1.82876 \\
Indirect metalinguistic & 4.9760 & 5.45360 \\
Control group & 9.8970 & 5.24807 \\
Total & 6.2920 & 5.06962 \\
\hline
\end{tabular}

Table 6. One-way ANOVA for error scores of revision

\begin{tabular}{llllll}
\hline & Sum of Squares & Df & Mean Square & F & Sig. \\
\hline Between Groups & 199.674 & 2 & 99.837 & 4.940 & .015 \\
Within Groups & 545.656 & 27 & 20.209 & & \\
Total & 745.330 & 29 & & & \\
\hline
\end{tabular}

According to the result reported in table 5 difference between groups is very significant $\mathrm{F}(2,27)=4.940, \mathrm{P}=.015$ in their revised texts. Thus Post Hoc tests were used to acknowledge which group or groups improved significantly on their revised texts. Tukey HSD Post Hoc test specified that both experiment groups i.e. DMF group $(\mathrm{M}=4.00, \mathrm{SD}=1.82)$, IMF group $(\mathrm{M}=4.97, \mathrm{SD}=5.45)$ differ significantly in terms of their error rates from Control group $(M=9.89, S D=5.24)$ while the difference between DMF and IMF was not statistically significant in their revised texts. In other words learners were able to gain benefits from WCF. Both types (direct, indirect) of feedback allowed low-intermediate pupils to reduce their errors while revising their original drafts while control group's rate remained constant.

\subsection{Analysis of Immediate Posttest}

Post-test incorporated new piece of writing to examine the accuracy on learner's new texts. One-way ANOVA was conducted to examine the short-term achievement as far as new piece of writing is concerned. Analyses are summed up in table 7,8 and 9 below:

Table 7. Percentage of errors (sum of errors/sum of words x100)

\begin{tabular}{ll}
\hline Groups & $\begin{array}{l}\text { Immediate Post-test } \\
\text { error scores }\end{array}$ \\
\hline Direct metalinguistic & $53.98 \%$ \\
Indirect metalinguistic & $70.85 \%$ \\
Control group & $131.41 \%$ \\
\hline
\end{tabular}

Table 8. Descriptive statistics of error scores of post-test across three groups

\begin{tabular}{lll}
\hline Groups & \multicolumn{2}{l}{ Error rate in post-test } \\
\hline & $\mathrm{M}$ & $\mathrm{SD}$ \\
\hline Direct metalinguistic & 5.3980 & 1.84396 \\
Indirect metalinguistic & 7.0850 & 3.03298 \\
Control group & 13.1410 & 5.13784 \\
Total & 8.5413 & 4.85142 \\
\hline
\end{tabular}


Table 9. One-way ANOVA for error scores of post-test

\begin{tabular}{llllll}
\hline & Sum of Squares & Df & Mean Square & F & Sig. \\
\hline Between Groups & 331.584 & 2 & 165.792 & 12.754 & .000 \\
Within Groups & 350.969 & 27 & 12.999 & & \\
Total & 682.553 & 29 & & & \\
\hline
\end{tabular}

The analysis detailed above demonstrates that the difference between groups was highly significant $\mathrm{F}(2,27)=$ $12.754, \mathrm{P}=.000$ in post-test. In order to determine which group or groups were able to retain the accuracy on post-test, Tukey Post Hoc tests were used. Results again indicated that both the treatment group outperformed the control group.

There is a significant difference between DMF group $(\mathrm{M}=8.03396, \mathrm{SD}=1.84396)$ and control group $(M=13.1410, S D=5.13784)$. Similarly IMF group $(M=7.0850, S D=3.03298)$ significantly differ in terms of error rate from control group. In other words both treatments resulted in short-term gains on learners' new piece of writing as compared to control group whose error rate increased on new piece of writing. Nonetheless, it can be observed that the difference in mean scores and percentage values indicated that only direct WCF group was able to retain the accuracy which they achieved during revision. However the difference between treatment groups is not statistically significant.

\subsection{Analysis of Delayed Posttest}

As described above One-way ANOVA was used to determine the delayed or long-term effects of WCF on new piece of writing. Delayed posttest was conducted after two weeks of the feedback. The results are presented in the tables below:

Table 10. Percentage of errors (sum of errors/sum of words x100)

\begin{tabular}{ll}
\hline Groups & $\begin{array}{l}\text { Delayed Post-test } \\
\text { error scores }\end{array}$ \\
\hline Direct metalinguistic & $64.4 \%$ \\
Indirect metalinguistic & $85.96 \%$ \\
Control group & $166.5 \%$ \\
\hline
\end{tabular}

Table 11. Descriptive statistics of error scores of delayed post-test across three groups

\begin{tabular}{lll}
\hline Groups & \multicolumn{2}{l}{ Error rate in delayed post-test } \\
\hline & $\mathrm{M}$ & $\mathrm{SD}$ \\
\hline Direct metalinguistic & 6.4400 & 3.43070 \\
Indirect metalinguistic & 8.5960 & 3.52780 \\
Control group & 16.6500 & 8.03396 \\
Total & 10.5620 & 6.89336 \\
\hline
\end{tabular}

Table 12. One-way ANOVA for error scores of post-test

\begin{tabular}{llllll}
\hline & Sum of Squares & Df & Mean Square & F & Sig. \\
\hline Between Groups & 579.198 & 2 & 289.599 & 9.788 & .001 \\
Within Groups & 798.836 & 27 & 29.587 & & \\
Total & 1378.034 & 29 & & & \\
\hline
\end{tabular}

Analysis of variance illustrates tremendously significant difference on delayed post-test, $\mathrm{F}(2.27)=9.788, \mathrm{P}=.001$. The Tukey HSD showed that experimental groups i.e. DMF $(M=6.4400, S D=3.43070)$ and $\mathrm{IMF}(\mathrm{M}=8.5960$, $\mathrm{SD}=3.52780)$ varied significantly from control group $(\mathrm{M}=16.6500, \mathrm{SD}=8.03396)$ at $\mathrm{P}<0.05$. However mean error rate or percentage values indicated that DMF performed slightly better than IMF but Post Hoc tests didn't indicate any significant differences. Conversely it is interesting to note that control group as shown in the table 7 and 8 increased their error rate on delayed post-test as compared to their pre-test. This signifies that WCF in both forms resulted in long-term gains on learners' new piece of writing. It helped low-intermediate learners to reduce their errors even after four weeks on new piece of writing as compared to control group who, when given an opportunity to write several times without any feedback, end up with high error rate on their last draft. 


\section{Discussion and Findings}

The results revealed that learners who received WCF treatment in the form of DMF and IMF were able to reduce their errors on revision and subsequent drafts. Both of the treatment groups were able to retain the accuracy that they achieved during revision session on I-posttest as well as on D-posttest. Analysis of variance (ANOVA) and Post Hoc test using Tukey confirmed that the accuracy gains on writing drafts by experimental groups was significant as compared to control group who didn't receive any feedback.. These results support the findings of previous studies (Bitchener, 2008, Bitchener \& Knoch, 2009a; Bitchener \& Knoch, 2009b; Bitchener \& Knoch, 2010; Sheen, 2007; Sheen et al., 2009) that investigated the effectiveness of WCF on lower proficiency learners in different ESL/EFL settings and found positive effects on their revision and new pieces of writing.

The first objective of this research was to investigate the extent to which learners reduced their errors on revised texts. Like some recent studies (Bithener, 2008; Bitchener \& Knoch, 2008; 2010) who investigated low-intermediate proficiency learners and those with high-intermediate proficiency participants (Ellis et al., 2008; Sheen, 2007; Sheen et al., 2009), the present study found that focused feedback guide low-intermediate learners to reduce errors on their revised texts. As it can be seen in Table 1 and Table 4 that learners of DMF group produced $104 \%$ error in pre-test and the error rate went down to $40 \%$ on their revision task. IMF group produced $102 \%$ errors on pre-test and error rate reduced down to $50 \%$ on revision task. While control group produced $101 \%$ error on pre-test that went down with the slightest reduction of errors to $98 \%$ on revision task. So it is safe to conclude that to a great extent WCF helped treatment groups to reduce their error rates on revision task.

The statistical tests indicated that both groups' receiving DMF and IMF outperformed on feedback group. Experimental groups were able to reduce errors on their revision unlike the control group whose error rate didn't change significantly from pre-test to revision task. One reason for why control group didn't reduce error rate on revised texts was that treatment groups were provided with feedback therefore they tried to process and attend the feedback and focus on correcting errors. On the contrary, control group didn't focus to correct their grammar errors particularly because their attention was not drawn towards grammatical errors (Beuningen et al., 2012). Thus it can be concluded that the reduction of errors are due to WCF and not writing the revision alone, as Schmidt (1990) argued that noticing is a prerequisite for learning which can only be triggered through feedback. This confirmed the findings of Truscott and Hsu (2008), Beuningen et al. $(2008,2012)$ who like the present study provided feedback treatment only one time on their single draft and found positive effect of direct and indirect WCF in improving accuracy on learners' revision. While the findings contradict the claims of early researches (Cohen \& Robbins, 1976; Truscott, 1996; Zamel, 1985) that learners didn't notice the error correction when provided by their instructors or didn't improve accuracy on their revised texts.

Early studies were conducted in language learning or L2 classrooms where aim of WCF was to improve students' drafts so that they could produce error free revisions. The aim of WCF was limited to short-term gains where error free revised version of first draft was considered as a hallmark for learning. Later it was realized that revised draft is not sufficient evidence for learning rather students must produce new piece of writing and compare the results with those who didn't receive WCF. Thus empirical researches were conducted by Beuningen et al. $(2008,2012)$ and Truscott and Hsu (2008). Following this the study aims at investigating both short-term and long-term effects on learners' immediate and delayed posttest respectively.

The second objective of this study was to determine the extent to which learners decrease or increase their error rate on I-posttest and D-post-test. According to Table 7 DMF group produced 53.98\% error on I-post-test and IMF produced $70.85 \%$ which is comparatively lower than the control group with $131.41 \%$ error rate. Thus following Ferris (2004), who argued that the comparison of feedback and no feedback group can produce systematic and reliable result regarding the effectiveness of WCF, it can be claimed that to a great extent WCF enabled learners to reduce errors on their immediate post-test when compared with control group. The statistical tests showed that DMF and IMF were able to retain the accuracy on new piece of writing on their immediate post-test. However mean error rate indicated an advantage of DMF who had fewer error rates than the IMF group but both the groups outperformed the control group. In order to determine the long-term effects, a D-posttest was administered after 4 weeks and results suggested that DMF performed slightly better than IMF group but again both the groups performed significantly better than the control group. DMF produced $64 \%$ errors; IMF produced $85 \%$ errors that are comparatively lower than the control group who produced $166 \%$ errors on D-post-test. The reason for DMF group to perform well might be that learners were at lower proficiency level and needed an explicit correction of their errors but on the other hand IMF proved to be beneficial for lower-proficiency learners who were able to maintain the accuracy on new piece of writing on both I-posttest and D-posttest. These findings contrast from Liu (2008) study, who found both direct and indirect as non-beneficial on new piece of writing after four weeks. 
However, it is interesting to note that the mean error scores of experimental groups in D-posttest increased as compared to their revision or posttest scores but decreased as compared to their pre-test scores. One reason why feedback group increased their errors might be the type of genre used in the experiment i.e. picture composition which may have constrained learners to focus less on grammar and more on story writing though there is no such evidence in this regard.

According to the results illustrated above, the answer to the second research question regarding the efficacy of WCF in reducing errors on I-posttest or D-posttest is that both the types have positive long and short-term effects Moreover, through a meticulous observation researchers can conclude the answer of third research question that both DMF and IMF appear to be the most effective treatments in addressing low-intermediate pupils' errors in this present study. The findings in support of direct and indirect WCF for both long and short-term effects confirmed the theoretical arguments that indirect feedback helped learners to activate their cognitive problem solving skills (Ferris, 2004) when they corrected themselves which ultimately led to long-term acquisition of those targeted forms (Ferris, 1995; Lalande, 1982). On the other hand, direct or explicit feedback clarified the confusion, if learners fail to understand the feedback and confirmed their hypothesis regarding the correct usage of targeted forms (Chandler, 2003). Furthermore, the long-held assumption or prediction in the literature advances that learners with high proficiency benefit more from indirect feedback as compared to learners with lower proficiency who need direct feedback because of the their limited processing capacity. Whereas, this study proved that learners, at least in this particular context with low-intermediate proficiency can benefit from indirect feedback when combined with metalinguistic feedback.

Since control group in the present study generated four drafts without receiving any feedback, consequently they failed to reduce grammatical errors throughout the experiment. In addition to this, descriptive statistics proved that the error rate of this group increased from their first draft to their last draft. The fact that writing practice alone doesn't yield any positive results led to discard one of the Truscott (2007) claim that teacher should encourage their students to utilize their time in producing extra writing outputs rather than just wasting time on correcting their errors. Findings of the early studies (Chandler, 2003) supported this claim of Truscott (2007) are not supported by the present study. Another possible explanation of why participants in control group increased their error rates on subsequent writing could be the lack of interest/motivation as the study moved on. Participants in the study knew that their drafts would not be marked or wouldn't affect their academic performance, secondly the experiment required learners to produce the same type of writing four times, and all these factors might had an effect on their intrinsic or extrinsic motivation (Bitchener, 2012). Truscott (2007) in his published article also criticized the recent studies by arguing that learner in their I-posttest or D-posttest tried to avoid targeted forms in order to make fewer errors and end up writing short and simplified texts. But this claim is refuted by the present study because the errors were calculated out of total number of actual usage. Moreover, the type of writing chosen for the study required learners to use the article and past tense extensively. Students may try to avoid the targeted forms but it is not possible to avoid them throughout the text.

\section{Limitations and Recommendations}

The findings of the present study provided clear evidence in favor of WCF, particularly DMF and IMF, as identified by Sheen (2011) had positive effects on low-intermediate learners writing. But there are certain limitations that need to be explored by future researchers. Some of the limitations that came into notice after the current study are listed below.

1. Learner's expectations, their learning and their daily classroom practices regarding WCF might have affected the results. Researchers in the future research may wish to control these variable effects. There is a probability that participants in the present study had never received direct feedback with metalinguistic explanation or error codes along with underlining the errors. They might be in need of more training to process or understand the feedback completely.

2. In the present study, due to shortage of time, the treatment to experimental groups was provided on a single draft only once. Researchers in future may want to know the outcome if the same treatment with similar feedback types is provided multiple times to low-intermediate or to other proficiency learners to see their short term and long-term effects.

3. Participants began the study with same proficiency level but differed in terms of their processing of feedback. Few of them in experimental group failed to get benefits, while others responded positively towards WCF. Secondly, during the experiment few of the learners in both DMF and IMF groups began to over generalize the use of targeted forms i.e. past tense and two uses of English articles. In order to have an in depth analysis of these issues, future researchers should probe into social and contextual factors of learners that might 
affect the way learners process or attend to feedback. A study of qualitative nature is suitable to investigate the adverse effects of WCF.

4. Error categories are delimited to two types, i.e. two uses of article system and past tense. It is recommended that future research must investigate other error categories such as lexical, syntactic, morphological and grammatical forms.

5. Future research can also be conducted at tertiary, college and university level of Quetta city.

\section{Implications}

The findings of this study are good and encouraging news for those teachers and instructors who spend hours in correcting errors of their students with the sole purpose of improving accuracy of L2 learners on writing. As learners in the present study noticed error correction on their first draft and were able to reduce errors on subsequent tests. Furthermore, they were immediately given an opportunity to revise their drafts and implement what they had learned from instructors' correction. This suggests a need for teachers to consider revision practice in their classrooms; it might have a positive effect on L2 learner's development. Thus it is safe to suppose that L2 learners benefit from feedback under certain conditions. Therefore, pedagogists in this particular EFL setting should consider it as valuable tool and train their teachers or instructors so that they can provide WCF to L2 learners in an organized and systematic way.

\section{References}

Bitchener, J. (2008). Evidence in support of written corrective feedback. Journal of Second Language Writing, 17(2), 102-118. https://doi.org/10.1016/j.jslw.2007.11.004

Bitchener, J. (2012). Written corrective feedback for L2 development: Current knowledge and future research. TESOL Quarterly, 46(4), 855-860. https://doi.org/10.1002/tesq.62

Bitchener, J., \& Ferris, D. R. (2012). Written Corrective Feedback in Second Language Acquisition and Writing. Routledge.

Bitchener, J., \& Knoch, U. (2008). The value of written corrective feedback for migrant and international students. Language Teaching Research, 12(3), 409-431. https://doi.org/10.1177/1362168808089924

Bitchener, J., \& Knoch, U. (2009a). The relative effectiveness of different types of direct written corrective feedback. System, 37(2), 322-329. https://doi.org/10.1016/j.system.2008.12.006

Bitchener, J., \& Knoch, U. (2009b). The value of a focused approach to written corrective feedback. ELT Journal, 63(3), 204-211. https://doi.org/10.1093/elt/ccn043

Bitchener, J., \& Knoch, U. (2010). Raising the linguistic accuracy level of advanced L2 writers with written corrective feedback. Journal of Second Language Writing, 19(4), 207-217. https://doi.org/10.1016/j.jslw.2010.10.002

Bitchener, J., Young, S., \& Cameron, D. (2005).The effect of different types of corrective feedback on ESL student writing. Journal of Second Language Writing, 14(3), 191-205. https://doi.org/10.1016/j.jslw.2005.08.001

Brooks, N. (1960). Language and language learning. New York: Harcourt

Chandler, J. (2003). The efficacy of various kinds of error feedback for improvement in the accuracy and fluency of L2 student writing. Journal of Second Language Writing, 12(3), 267-296. https://doi.org/10.1016/S1060-3743(03)00038-9

Chaudron, C. (1988). Second Language Classrooms: Research on Teaching and Learning. Cambridge University Press. https://doi.org/10.1017/CBO9781139524469

Chomsky, N. (1959). A review of BF Skinner's Verbal Behavior. Language, 35(1), 26-58. https://doi.org/10.2307/411334

Chunhong, Z., \& Griffiths, C. (2012). Quantitative and qualitative perspectives on individual differences in error correction preferences. In New Perspectives on Individual Differences in Language Learning and Teaching, Springer Berlin Heidelberg, 305-317. https://doi.org/10.1007/978-3-642-20850-8_19

Cohen, A. D., \& Robbins, M. (1976). Toward assessing interlanguage performance: The relationship between selected errors, learners' characteristics, and learers' explanations. Language Learning, 26(1), 45-66. https://doi.org/10.1111/j.1467-1770.1976.tb00259.x 
Cramp, A. (2011). Developing first-year engagement with written feedback. Active Learning in Higher Education, 12(2), 113-124. https://doi.org/10.1177/1469787411402484

Elawar, M. C., \& Corno, L. (1985). A factorial experiment in teachers' written feedback on student homework: Changing teacher behavior a little rather than a lot. Journal of Educational Psychology, 77(2), 162. https://doi.org/10.1037/0022-0663.77.2.162

Ellis, N. C. (2005). At the interface: How explicit knowledge affects implicit language learning. Studies in Second Language Acquisition, 27(2), 305-352. https://doi.org/10.1017/S027226310505014X

Ellis, R. (2009). A typology of written corrective feedback types. ELT Journal, 63(2), 97-107. https://doi.org/10.1093/elt/ccn023

Ellis, R., Sheen, Y., Murakami, M., \& Takashima, H. (2008). The effects of focused and unfocused written corrective feedback in an English as a foreign language context. System, 36(3), 353-371. https://doi.org/10.1016/j.system.2008.02.001

Fathman, A., \& Whalley, E. (1990). Teacher response to student writing: Focus on form versus content. Second language writing: Research Insights for the Classroom, 9, 178-190. https://doi.org/10.1017/CBO9781139524551.016

Fazio, L. (2001). The effect of corrections and commentaries on the journal writing accuracy of minority- and majority-language students. Journal of Second Language Writing, 10(4), 235-249. https://doi.org/10.1016/S1060-3743(01)00042-X

Ferris, D. (1999). The case for grammar correction in L2 writing classes: A response to Truscott (1996). Journal of Second Language Writing, 8(1), 1-11. https://doi.org/10.1016/S1060-3743(99)80110-6

Ferris, D. R. (1995). Student reactions to teacher response in multiple - draft composition classrooms. TESOL Quarterly, 29(1), 33-53. https://doi.org/10.2307/3587804

Ferris, D. R. (2004). The "grammar correction" debate in L2 writing: Where are we, and where do we go from here? (and what do we do in the meantime...?). Journal of Second Language Writing, 13(1), 49-62. https://doi.org/10.1016/j.jslw.2004.04.005

Ferris, D. R. (2006). Does error feedback help student writers? New evidence on the short-and long-term effects of written error correction. Feedback in Second Language Writing: Contexts and Issues, 81104.

Ferris, D. R. (2010). Second language writing research and written corrective feedback in SLA. Studies in Second Language Acquisition, 32(02), 181-201. https://doi.org/10.1017/S0272263109990490

Ferris, D., \& Hedgecock, J. S. (1998). Building a community of writers: Principles of peer response. Teaching ESL Composition: Purpose, Process, and Practice, 169-189.

Ferris, D., \& Roberts, B. (2001). Error feedback in L2 writing classes: How explicit does it need to be?. Journal of second language writing, 10(3), 161-184. https://doi.org/10.1016/S1060-3743(01)00039-X

Gass, S. M., \& Selinker. (2001). Second language acquisition: An introductory course. Routledge.

Glover, C., \& Brown, E. (2006). Written feedback for students: too much, too detailed or too incomprehensible to be effective?. Bioscience Education, 7(1), 1-16. https://doi.org/10.3108/beej.2006.07000004

Guénette, D. (2007). Is feedback pedagogically correct?: Research design issues in studies of feedback on writing. Journal of second language writing, 16(1), 40-53. https://doi.org/10.1016/j.jslw.2007.01.001

Hattie, J., Biggs, J., \& Purdie, N. (1996). Effects of learning skills interventions on student learning: A $\begin{array}{lllll}\text { meta-analysis. Review of } & \text { Educational }\end{array}$ https://doi.org/10.3102/00346543066002099

Hendrickson, J. M. (1978). Error correction in foreign language teaching: Recent theory, research, and practice. The Modern Language Journal, 62(8), 387-398.

Hyland, F., \& Hyland, K. (2001). Sugaring the pill: Praise and criticism in written feedback. Journal of second language writing, 10(3), 185-212. https://doi.org/10.1016/S1060-3743(01)00038-8

Lalande, J. F. (1982). Reducing composition errors: An experiment. The Modern Language Journal, 66(2), 140-149. https://doi.org/10.1111/j.1540-4781.1982.tb06973.x

Li, S. (2010). The effectiveness of corrective feedback in SLA: A meta - analysis. Language Learning, 60(2), 309-365. https://doi.org/10.1111/j.1467-9922.2010.00561.x 
Lightbown, P. M., \& Spada, N. (1999). How Languages are Learned. Oxford, UK: Oxford University Press.

Lightbown, P. M., \& Spada, N. (2013). How Languages are Learned (4th ed.). Oxford University Press.

Liu, Y. (2008). The effects of error feedback in second language writing. Arizona Working Papers in SLA \& Teaching, 15(1), 65-79.

Long, M. H. (1996). The role of the linguistic environment in second language acquisition. Handbook of Second Language Acquisition, 2(2), 4131-468. https://doi.org/10.1016/B978-012589042-7/50015-3

Myles, J. (2002). Second language writing and research: The writing process and error analysis in student texts. Tesl-Ej, 6(2), 1-20.

Polio, C., \& Fleck, C. (1998). "If I only had more time:" ESL learners' changes in linguistic accuracy on essay $\begin{array}{lllll}\text { revisions. Journal of Second Language Writing, } & \text { 7(1), }\end{array}$ https://doi.org/10.1016/S1060-3743(98)90005-4

Robb, T., Ross, S., \& Shortreed, I. (1986). Salience of feedback on error and its effect on EFL writing quality. TESOL Quarterly, 20(1), 83-96. https://doi.org/10.2307/3586390

Russell, J., \& Spada, N. (2006). The effectiveness of corrective feedback for the acquisition of L2 grammar. Synthesizing research on language learning and teaching, 133-164.

Scardimalia, M., \& Bereiter, C. (1987). The psychology of written composition. Lawrence Erlbaum.

Schachter, J. (1991). Corrective feedback in historical perspective. Interlanguage Studies Bulletin (Utrecht), 7(2), 89-102. https://doi.org/10.1177/026765839100700202

Schmidt, R. (1994). Deconstructing consciousness in search of useful definitions for applied linguistics. Consciousness in Second Language Learning, 11, 237-326.

Schmidt, R. W. (1990). The role of consciousness in second language learning1. Applied Linguistics, 11(2), 129-158. https://doi.org/10.1093/applin/11.2.129

Semke, H. D. (1984). Effects of the red pen. Foreign language annals, 17(3), 195-202. https://doi.org/10.1111/j.1944-9720.1984.tb01727.x

Sheen, Y. (2007). The effect of focused written corrective feedback and language aptitude on ESL learners' acquisition of articles. Tesol Quarterly, 41(2), 255-283. https://doi.org/10.1002/j.1545-7249.2007.tb00059.x

Sheen, Y. (2011). Corrective Feedback, Individual Differences and Second Language Learning. Springer. https://doi.org/10.1007/978-94-007-0548-7

Sheen, Y., Wright, D., \& Moldawa, A. (2009). Differential effects of focused and unfocused written correction on the accurate use of grammatical forms by adult ESL learners. System, 37(4), 556-569. https://doi.org/10.1016/j.system.2009.09.002

Truscott, J. (1996). The case against grammar correction in L2 writing classes. Language Learning, 46(2), 327-369. https://doi.org/10.1111/j.1467-1770.1996.tb01238.x

Truscott, J. (2007). The effect of error correction on learners' ability to write accurately. Journal of Second Language Writing, 16(4), 255-272. https://doi.org/10.1016/j.jslw.2007.06.003

Truscott, J., \& Hsu, A. Y. P. (2008). Error correction, revision, and learning. Journal of Second Language Writing, 17(4), 292-305. https://doi.org/10.1016/j.jslw.2008.05.003

Trustcott, J. (1999). The case for "the case for grammar correction in L2 writing classes": A response to Ferris. Journal of Second Language Writing, 8, 111-122Ur. https://doi.org/10.1016/S1060-3743(99)80124-6

Van Beuningen, C. G., De Jong, N. H., \& Kuiken, F. (2008). The effect of direct and indirect corrective feedback on L2 learners' written accuracy. ITL International Journal of Applied Linguistics, 156, 279-296. https://doi.org/10.1075/itl.156.24beu

Van Beuningen, C. G., De Jong, N. H., \& Kuiken, F. (2012). Evidence on the effectiveness of comprehensive error correction in second language writing. Language Learning, 62(1), 1-41. https://doi.org/10.1111/j.1467-9922.2011.00674.xV

Zamel, V. (1985). Responding to student writing. Tesol Quarterly, 19(1), 79-101. https://doi.org/10.2307/3586773 


\section{Copyrights}

Copyright for this article is retained by the author, with first publication rights granted to the journal.

This is an open-access article distributed under the terms and conditions of the Creative Commons Attribution license (http://creativecommons.org/licenses/by/4.0/). 